\title{
Synthesis, Characterization and Antimicrobial Activity of Some Organotin (IV) Complexes with a Potassium Hydrogen Ethanedioate Ligand
}

\author{
Iornumbe, E. N. ${ }^{1}$, Yiase, S. G. ${ }^{2}$, Tor-Anyiin, T. A. ${ }^{3}$ \\ ${ }^{1,3}$ Inorganic Chemistry Research Group, University of Agriculture, P.M.B. 2373, Makurdi, 970001 - Nigeria \\ ${ }^{2}$ Department of Chemistry, Benue State University, Makurdi - Nigeria
}

\begin{abstract}
Four series of organotin (IV) derivatives of potassium hydrogen ethanedioate: $\mathrm{Bu}_{2} \mathrm{SnL}_{2}, \mathrm{Bu}_{3} \mathrm{SnL}_{\mathrm{B}} \mathrm{Ph}_{2} \mathrm{SnL}_{2}{\text { and } P h_{3} S n L}_{\mathrm{have}}$ been synthesized characterized by tin content analysis, FTIR, ${ }^{1} \mathrm{H} N \mathrm{NR}$ and ${ }^{13} \mathrm{C} N \mathrm{NR}$ and tested for antimicrobial activity against four Gram-positive bacteria: Staphylococcus aureus, Streptococcus pyogenes, Bacillus cereus, Corynebacterium ulcerans, four Gramnegative Bacteria: Escherichia coli, Klebsiella pneumoniae, Proteus mirabilis and Pseudomonas aeruqinosa and four fungi strains of Microsporum spp: Microsporum audounii, Microsporum distortum, Microsporum qallinae and Microsporum gypseum. Result showed that the compounds synthesized in general exhibited greater antimicrobial activity than potassium hydrogen ethanedioate. Organotin moieties play a vital role in deciding the antimicrobial activity of an organotin compound, this is true in this work. The order for the antifungal activity in this study was $\mathrm{Bu}_{3} \mathrm{SnL}>\mathrm{Ph}_{3} \mathrm{SnL}>\mathrm{Ph}_{2} \mathrm{SnL}_{2}>\mathrm{Bu}_{2} \mathrm{SnL}_{2}$. The order of activity against gram-positive bacteria was $\mathrm{Ph}_{3} \mathrm{SnL}>\mathrm{Bu}_{2} \mathrm{SnL}_{2}>\mathrm{Ph}_{2} \mathrm{SnL}_{2}>\mathrm{Bu}_{3} \mathrm{SnL}$. The order of activity against gram-negative bacteria was $\mathrm{Bu}_{3} \mathrm{SnL}^{>} \mathrm{Bu}_{2} \mathrm{SnL}_{2}>\mathrm{Ph}_{2} \mathrm{SnL}_{2}>$ $\mathrm{Ph}_{3} \mathrm{SnL}$.
\end{abstract}

Keywords: Organotin derivatives, potassium hydrogen ethanedioate, Spectroscopic techniques, Antimicrobial activity

\section{Introduction}

Organotin complexes are known to attract more attention in recent years owing partly to their potential pharmaceutical value [1] as well as their potentials as biocides, homogenous catalysts, antifouling agents [2], antineoplastic [3] and antituberculosis agents [4]. As a result, they have found wide application in agriculture, industries and medicine [5]. The high coordination ability of tin, especially its ability to participate either in weak or strong intra or intermolecular coordination [6], has given organotin (IV) chemistry wide recognition. Tin compounds have a fascinating solution and solid phase chemistry [7]. The coordination characteristics of tin and the structures differ dramatically in solution and in solid state when a nucleophilic group is present in the tin moiety or when an organic group is linked by a $\mathrm{Sn}-\mathrm{C}$ bond [8] and bears additional functionality with donor properties due to the presence of $\mathrm{O}, \mathrm{N}$ and $\mathrm{S}$ as donor atoms [2]-[6].

Organotin (IV) carboxylates are widely studied compounds with structural diversity and finds pharmaceutical applications [2] especially with reference to their antitumour [8] and anti-tuberculosis [9] activities. In the presence of additional coordinating atoms, some organotin carboxylates have fascinating structures, such as hexameric cyclic forms with a wide variety of coordination geometries [4], [10]. The combination of steric and electronic factors determine the specific structure adapted by a particular carboxylate [4], which could be monomeric, dimeric, tetrameric, oligomeric, cyclic and hexameric drum. It has been reported that the different structural types are formed due to the presence of additional coordinating sites ( $\mathrm{S}, \mathrm{N}$ or $\mathrm{O}$ ) along with a carboxylic moiety [7]. In recent years, organotin (IV) carboxylates have been a subject of interest for some time because of their biochemical and commercial applications.
Generally, the biochemical activity of organotin (IV) carboxylates is greatly influenced by the structure of the molecule and the coordination number of the tin atom. Recognition of the importance between the biological properties and the structure of organotin (IV) carboxylates has stimulated the study of carboxylates of tin [11].

In an attempt to further explore the interesting features of organotin compounds based on the above, we report here the synthesis, characterization and antimicrobial properties of four organotin (IV) dicarboxylates prepared from four parent organotin compounds and ethanedioc acid.

\section{Materials and Methods}

Glass wares and Dean-Stack apparatus with standard quick fit joints were used throughout the work after cleaning and drying at $120{ }^{\circ} \mathrm{C}$. Ethanedioc acid, $\mathrm{KOH}$, parent organotins: dibutyltin (IV) oxide: $\left(\mathrm{C}_{4} \mathrm{H}_{9}\right)_{2} \mathrm{SnO}$, tributyltin (IV) hydroxide: $\left(\mathrm{C}_{4} \mathrm{H}_{9}\right)_{3} \mathrm{SnOH}$, diphenyltin (IV) oxide: $\left(\mathrm{C}_{6} \mathrm{H}_{5}\right)_{2} \mathrm{SnO}$ and triphenyltin (IV) hydroxide: $\left(\mathrm{C}_{6} \mathrm{H}_{5}\right)_{3} \mathrm{SnOH}$ were purchased from Sigma-Aldrich Chemical Company (Germany) and used as such. The solvents: methanol, propanol, and DMSO were Sigma- Aldrich products of analytical grade with purity ranging from $98-99.8 \%$.

\subsection{Synthesis of potassium hydrogen ethanedioate (L)}

Potassium hydroxide ( $0.05 \mathrm{~mol}, 2.8338 \mathrm{~g})$ was completely dissolved in $50 \mathrm{~mL}$ distilled water in a $250 \mathrm{~mL}$ flat bottom flask containing a magnetic stirrer bar and ethanedioic acid $(0.0241 \mathrm{~mol}, 4.1920 \mathrm{~g})$ was added and refluxed for 1 hour until all have reacted giving a clear solution. After cooling in an ice-bath, crystals of potassium hydrogen ethanedioate separated out and were filtered in a Buchner filtering unit and dried to a constant weight in a desiccator [12]-[15]. 


\section{International Journal of Science and Research (IJSR) \\ ISSN (Online): 2319-7064}

Index Copernicus Value (2013): 6.14 | Impact Factor (2015): 6.391

2.2 Synthesis of potassium dibutyltin (IV) ethanedioate $\mathrm{Bu}_{2} \mathrm{SnL}_{2}$ (1) and potassium diphenyltin (IV) ethanedioate: $\mathrm{Ph}_{2} \mathrm{SnL}_{2}$ (3)

Dibutyltin (IV) oxide, 1.9506 g (0.0080 mol) was refluxed in a methanol-n-propanol mixture of ratio $4: 1$ in a $250 \mathrm{~mL}$ flask for five (5) hours using Dean and Stark apparatus to give a clear solution of the intermediate: dibutyltin (IV) dipropoxide. Water in the solution distilled off as an azeotrope at $96-98{ }^{0} \mathrm{C}$. After cooling, potassium hydrogen ethanedioate(L) $2.1063 \mathrm{~g}(0.008 \mathrm{~mol})$ was added and refluxed for an hour and kept in an oven at $40{ }^{\circ} \mathrm{C}$ to obtain a white crystalline product (1) [12]-[19]. Similar procedure was used in the synthesis of $\mathrm{Ph}_{2} \mathrm{SnL}_{2}$ (3) as in our earlier report [12],[14].

\subsection{Synthesis of potassium tributyltin (IV) ethanedioate: $\mathrm{Bu}_{3} \mathrm{SnL}(2)$ and potassium triphenyltin (IV) ethanedioate: $\mathrm{Ph}_{3} \mathrm{SnL}(4)$}

Tributyltin (IV) hydroxide, $0.5000 \mathrm{~g}$ (0.0008 mol,) and potassium hydrogen ethanedioate, $0.2085 \mathrm{~g} \quad$ (0.0008 mol) were suspended in methanol and refluxed for five hours between $60{ }^{0} \mathrm{C}$ to $70{ }^{0} \mathrm{C}$ in Dean and Stark apparatus. The methanol distilled off at $64.5^{0} \mathrm{C}$ leaving a white precipitate which was kept in an oven for 72 hours at $40{ }^{\circ} \mathrm{C}$ to give white crystalline solid of $\mathrm{Bu}_{3} \mathrm{SnL}$ (2). Same procedure [12]- [19] was also used in synthesizing $\mathrm{Ph}_{3} \mathrm{SnL}$ (4)

\subsection{Physicochemical Measurements}

Fansworth and Pekola method [20] was adopted for tin content analysis. Melting points were obtained with FisherJohns microscope hot stage melting point apparatus and were not corrected. Fourier transform infrared spectra in the range $4000-400 \mathrm{~cm}^{-1}$ were recorded using potassium bromide pellets on FTIR-8400S spectrophotometer (SHIMADZU). ${ }^{1} \mathrm{H}$ and ${ }^{13} \mathrm{C}$ NMR spectra were recorded at room temperature using NMR Nujol $400 \mathrm{MHz}$ spectrophotometer.

\subsection{Biological Investigations}

The antibacterial activity of the synthesized compounds was tested on four Gram-positive bacteria: Staphylococcus aureus, Streptococcus pyogenes, Bacillus cereus, corynebacterium ulcerans and four Gram-negative bacteria: Escherichia coli, Klebsiella pneumoniae, Proteus mirabilis and Pseudomonas aeruginosa in mueller hinton agar medium. The antifungal activity of the compounds was tested on the test fungi: Microsporum audounii, Microsporum distortum, Microsporum gallinae and Microsporum gypseum in Sabouraud dextrose agar. Clinical isolates of the microbes used were obtained from Institute for Agricultural Research (I.A.R) as well as Veterinary Medicine and Medicinal Microbiological Department, Ahmadu Bello University Teaching Hospital, Zaria. Agar well diffusion technique and dilution method were used, as in our earlier report [12], [14].

\subsubsection{Agar Well Diffusion Technique}

The method adopted for determination of antimicrobial activity of the organotin compounds was agar well diffusion technique. Sabouraud dextrose agar (SDA) and Mueller Hinton agar were used as culture media for fungi and bacteria respectively. They were prepared according to manufacturer's instructions, sterilized at $121{ }^{0} \mathrm{C}$ for 15 minutes, poured into sterile petri dishes under an aseptic hood and allowed to cool and solidify.

The sterile media were seeded with $0.1 \mathrm{~mL}$ of standard inoculums of the test microbes and spread evenly over the surfaces of the media using a sterile swab. A well was cut at the centre of each inoculated medium using a standard cork borer of $6 \mathrm{~mm}$ diameter and $200 \mu \mathrm{g} / \mathrm{mL}$ of the test compounds dissolved in DMSO were introduced into their respective wells. Other wells supplemented with reference antifungal and antibacterial drugs: fluconazole \& fulcin and erythromycin respectively were used as controls. The media were incubated at $30{ }^{0} \mathrm{C}$ for 7 days and at $37{ }^{0} \mathrm{C}$ for 24 hours for the fungi and bacteria respectively, and checked daily for inhibition zone: area where the microbes were unable to grow [21], [22].Where inhibition zones were not observed, the organotin used was inactive or concentration used may be less than required.

\subsubsection{Minimum Inhibition Concentration (MIC)- Broth Dilution Method}

The minimum inhibition concentrations (MICs), the lowest concentrations of the test compounds exhibiting no visible growth of bacteria or fungi, were determined by agar dilution method. Stock solutions of the synthesized compounds $(200 \mu \mathrm{g} / \mathrm{mL})$ in DMSO were prepared, and serial dilution in sterile Mueller Hinton broth for determination of antibacterial activity and in Sabouraud dextrose broth medium for antifungal activity was made to obtain the concentrations of $100 \mu \mathrm{g} / \mathrm{mL}, 50$ $\mu \mathrm{g} / \mathrm{mL}, 25 \mu / \mathrm{mL}$ and $12.5 \mu \mathrm{g} / \mathrm{mL}$. The broth were prepared in test tubes, sterilized at $121{ }^{0} \mathrm{C}$ for 15 minutes and allowed to cool. $1.5 \times 10^{5} \mathrm{CFU} / \mathrm{mL}$ of test fungi and $1.5 \times 10^{8}$ $\mathrm{CFU} / \mathrm{mL}$ of test bacteria in normal saline were made and introduced separately into each of the concentrations and incubated at $30{ }^{0} \mathrm{C}$ for 7 days (fungi) and at $37{ }^{\circ} \mathrm{C}$ for $24 \mathrm{hrs}$ (bacteria) [20]. The test tubes were observed for turbidity (growth) and the lowest concentration of a compound in the broth which showed no turbidity was recorded as the MIC. Contents of MIC in the serial dilution were sub cultured onto the prepared medium and incubated at $30{ }^{0} \mathrm{C}$ for 7 days and $37^{\circ} \mathrm{C}$ for 24 hrs for fungi and bacteria respectively. Plates were observed for colony growth, MFC was the plate with lowest concentration of compound without colony growth [4], [12]-[14]. Minimum fungicidal concentration (MFC) was determined in order to ascertain if the test microbes were completely killed or only inhibited.

\section{Results and Discussion}

\subsection{Synthesis}

Synthesis of organotin (IV) derivatives of potassium hydrogen ethanedioate (1, 2, 3 and 4) was successfully achieved from their oxides $\left[\left(\mathrm{C}_{4} \mathrm{H}_{9}\right)_{2} \mathrm{SnO},\left(\mathrm{C}_{6} \mathrm{H}_{5}\right)_{2} \mathrm{SnO}\right]$ and hydroxides $\left[\left(\mathrm{C}_{4} \mathrm{H}_{9}\right)_{3} \mathrm{SnOH},\left(\mathrm{C}_{6} \mathrm{H}_{5}\right)_{3} \mathrm{SnOH}\right]$, respectively. The reactions occurred in eight steps as shown in scheme 1 . The ligand: HOOCCOOK was first prepared by the reaction 


\section{International Journal of Science and Research (IJSR) \\ ISSN (Online): 2319-7064 \\ Index Copernicus Value (2013): 6.14 | Impact Factor (2015): 6.391}

between $\mathrm{KOH}$ and ethanedioic acid: $\mathrm{HOOCCOOH}$ according to route (I). $\left(\mathrm{C}_{4} \mathrm{H}_{9}\right)_{2} \mathrm{SnO}$ and $\left(\mathrm{C}_{6} \mathrm{H}_{5}\right)_{2} \mathrm{SnO}$ were refluxed separately in $4: 1 \mathrm{CH}_{3} \mathrm{OH}$ and $\mathrm{C}_{3} \mathrm{H}_{7} \mathrm{OH}$ (route II) yielding their respective propoxides as intermediates. These were further reacted with the ligand $\mathbf{L} \mathrm{HOOCCOOK}$ to produce compounds 1 and 3 (routes III and IV). $\left(\mathrm{C}_{4} \mathrm{H}_{9}\right)_{3} \mathrm{SnOH}$ and $\left(\mathrm{C}_{6} \mathrm{H}_{5}\right)_{3} \mathrm{SnOH}$ were refluxed in $\mathrm{CH}_{3} \mathrm{OH}$ which gave their dimethoxides as intermediates (routes V and VI respectively) which were further reacted with the ligand: HOOCCOOK to produce compounds $\mathbf{2}$ and $\mathbf{4}$ (VII and VIII). Water produced in the process was collected in the separator of Dean and Stark apparatus and removed from the reaction.

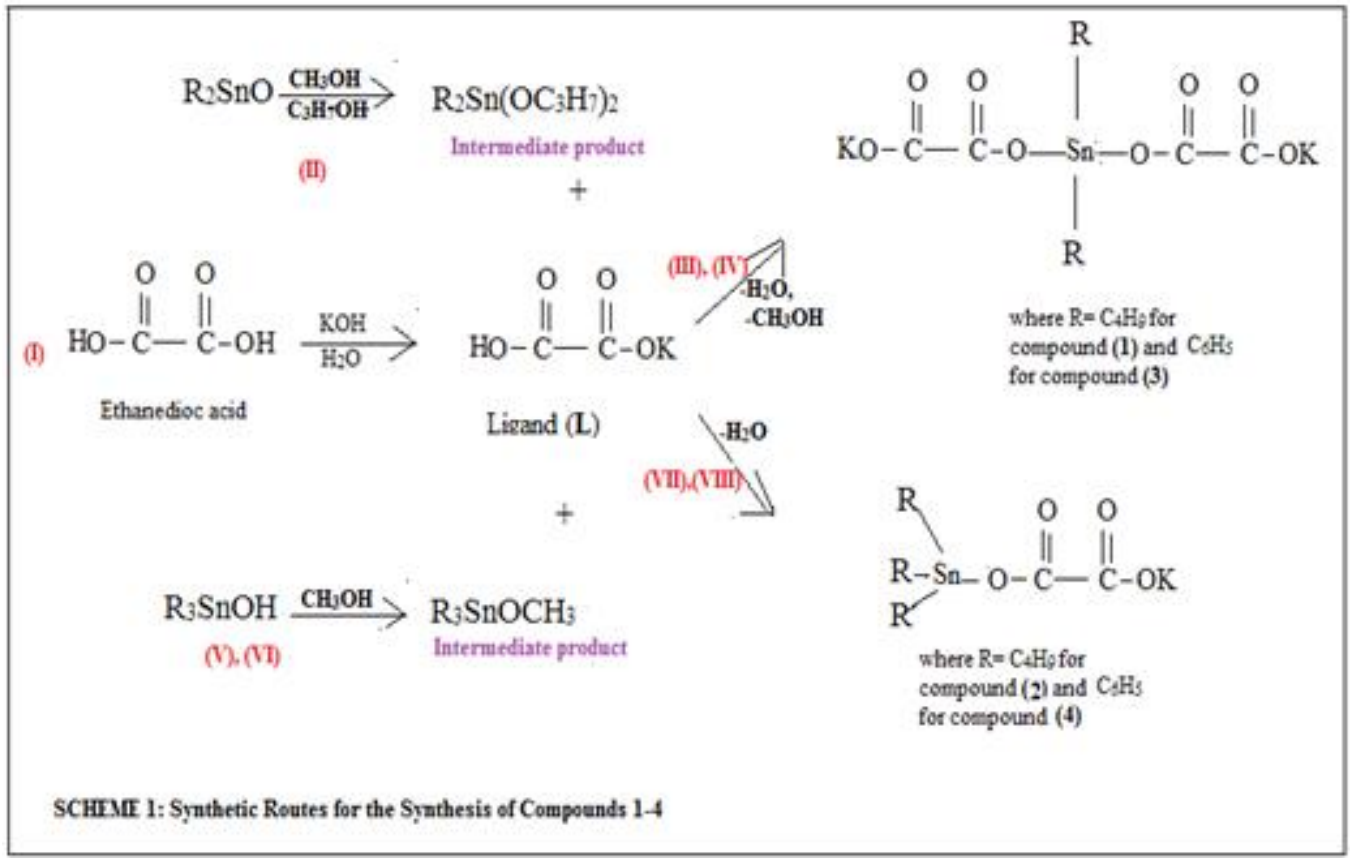

Table 1, shows the physicochemical data of synthesized compounds. Observed \% Sn was found to be in agreement with calculated tin content, an indication that the products were formed. The melting points of the compounds reflect their purity.

Table 1: Physicochemical Data of compounds synthesized

\begin{tabular}{llllr}
\hline Compound no. & \%Sn & & Mpt. & \%yield \\
\hline $\mathbf{l}^{*}$ & $24.43^{\mathrm{a}}$ & $24.49^{\mathrm{b}}$ & $340-344$ & 85.79 \\
$\mathbf{2}^{*}$ & 28.46 & 28.54 & $402-405$ & 92.48 \\
$\mathbf{3}^{*}$ & 21.87 & 21.58 & $288-289$ & 95.68 \\
$\mathbf{4}^{*}$ & 24.91 & 24.94 & $300-301$ & 92.16 \\
\hline
\end{tabular}

$\mathrm{a}=$ found, $\mathrm{b}=$ theoritical, $*=$ white crystals

\subsection{Infrared Spectroscopy}

Important Infrared absorption bands of synthesized compounds are listed in Table 2.

Table 2:Important IR bands of synthesized compounds $\left(\mathrm{cm}^{-1}\right)$

\begin{tabular}{|lllllc|}
\hline Compound no. & $\mathbf{l}$ & $\mathbf{2}$ & $\mathbf{3}$ & $\mathbf{4}$ & L \\
\hline $\mathrm{v}_{\text {assm }}(\mathrm{COO})$ & 1629 & 1643 & 1677 & 1663 & 1694 \\
$\mathrm{v}_{\mathrm{s} v \mathrm{~m}}(\mathrm{COO})$ & 1460 & 1464 & 1423 & 1432 & 1442 \\
$\Delta \mathrm{v}$ & 169 & 179 & 254 & 230 & 252 \\
$\mathrm{Sn}-\mathrm{O}$ & 411 & 501 & 515 & 445 & - \\
$\mathrm{Sn}-\mathrm{O}-\mathrm{C}$ & 1017 & 1029 & 906 & 906 & - \\
$\mathrm{Sn}-\mathrm{Bu}$ & 671 & 719 & - & - & - \\
$\mathrm{Sn}-\mathrm{Ph}$ & - & - & 1083 & 1072 & - \\
$\mathrm{C}-\mathrm{H}_{\text {arcm }}$ & - & - & 3050 & 3058 & - \\
O-H & - & - & - & - & 3486 \\
\hline
\end{tabular}

$\mathrm{L}=\mathrm{HOOCCOOK}$

The Fourier transform infrared spectrum of the ligand(L) showed characteristic stretching absorption bands at 3486 $\mathrm{cm}^{-1}, 1694 \mathrm{~cm}^{-1}$ and $1442 \mathrm{~cm}^{-1}$, which were assigned to $v(\mathrm{OH}), \quad v(\mathrm{COO})_{\text {asym }}$ and $v(\mathrm{COO})_{\text {sym }}$, respectively. The spectra of compounds (1-4) revealed absence of a strong vibrational frequency due to $\mathrm{OH}$ stretching at $3486 \mathrm{~cm}^{-1}$ which was present in the ligand. The presence of bands in the range 515-411 $\mathrm{cm}^{-1}$ and 1029-906 $\mathrm{cm}^{-1}$ indicated deprotonation of -COOH group and formation of new Sn-O and Sn-O-C bonds, respectively [23], [24]. Formation of the compounds was further confirmed by appearance of medium intensity bands in the range $1083-671 \mathrm{~cm}^{-1}$ due to $\mathrm{Sn}-\mathrm{C}-\mathrm{O}$, $\mathrm{Sn}-\mathrm{Bu}$ and $\mathrm{Sn}-\mathrm{Ph}$ bonds. The band at $3486 \mathrm{~cm}^{-1}$ which appeared in the free ligand as the $v(\mathrm{O}-\mathrm{H})$ stretching vibrations but absent in compounds 1-4, indicated metalligand bond formation through these sites [25]. The red shifts of the bands with respect to the free acid also served to confirm the formation of organotin carboxylates [10]. The binding mode of ligand to tin atom was determined by the difference between the asymmetric and symmetric carboxylate stretching vibrations, $\Delta v=v_{\text {asym }}(\mathrm{COO})$ and $v_{\text {sym }}(\mathrm{COO})$ [26]. Generally, it is believed that $\Delta v$ value $<200$ $\mathrm{cm}^{-1}$ indicates that the carboxylate moiety is bidentate, while $>200 \mathrm{~cm}^{-1}$ indicates monodentate [5],[23], [25]. The magnitude of $\Delta v$ of $179-169 \mathrm{~cm}^{-1}$ for complexes 1 and 2 indicated that the carboxylate ligands function as bidentate under the conditions employed while that of compounds 3 and 4 as well as the ligand (L) with values in the range 254 $230 \mathrm{~cm}^{-1}$ indicated their carboxylate groups as monodentate. It is, therefore, proposed that the carboxylate group in these compounds are acting as both bidentate and monodentate ligand [10], [27], [28]. 


\section{International Journal of Science and Research (IJSR) \\ ISSN (Online): 2319-7064}

Index Copernicus Value (2013): 6.14 | Impact Factor (2015): 6.391

\subsection{NMR Spectroscopy}

The ${ }^{1} \mathrm{H}$ NMR spectra of synthesized compounds are shown in Table 3. Signals of the protons in all the compounds were observed within the expected range. The expected aliphatic and aromatic peaks with correct integration and multiplicities were observed. Compounds $\mathbf{3}$ and $\mathbf{4}$ showed complex pattern in the range $7.34-7.76 \mathrm{ppm}$ due to the aromatic protons of phenyl groups. Figure 1, shows the numbering of protons and carbons in the structure of the compounds.

Table 3: ${ }^{1} \mathrm{H}$ NMR data of synthesized compounds and ligand

\begin{tabular}{|llllll|}
\hline Compound no. & $\mathbf{1}$ & $\mathbf{2}$ & $\mathbf{3}$ & $\mathbf{4}$ & L \\
\hline & & & & & \\
$\mathrm{a}$ & 1.23 & - & - & - & - \\
$\mathrm{b}$ & $1.41 \mathrm{~m}$ & - & - & - & - \\
$\mathrm{S}$ & $0.82 \mathrm{t}(7.2)-$ & - & - & - \\
$\alpha$ & 1.02 & - & - & - & - \\
$\beta$ & - & - & 7.76 & 7.66 & - \\
$\gamma$ & - & - & $7.34 \mathrm{~s}$ & 7.37 & - \\
$\delta$ & - & - & 7.51 & 7.47 & - \\
O-H & - & - & - & - & 9.99 \\
\hline
\end{tabular}

$\mathrm{L}=\mathrm{HOOCCOOK}$

a) Chemical $\operatorname{shift}(\delta)$ in ppm, $\mathrm{J}\left({ }^{1} \mathrm{H}-{ }^{1} \mathrm{H}\right)$

b) Multiplicity is given as $\mathrm{s}=$ singlet, $\mathrm{t}=$ triplet, $\mathrm{m}=$ multiplet

c) Fiqure 1 shows the numbers asigned to protons and carbons in the proposed structure of synthesized compounds for ease of reference.

Butyl protons found in compounds $\mathbf{1}$ designated $\mathbf{a}$ and $\mathbf{b}$ in fig. 1 , showed complex peaks due to $-\mathrm{CH}_{2}-\mathrm{CH}_{2}-\mathrm{CH}_{2}$ - in the range1.23 -1.41 ppm and a clear triplet due to the terminal methyl group designated c around $0.82 \mathrm{ppm}$ with $\left({ }^{1} \mathrm{H}-{ }^{1} \mathrm{H}\right)$ coupling of $7.2 \mathrm{~Hz}$. The methylene protons designated $\boldsymbol{\alpha}$, showed peak at $1.02 \mathrm{ppm}$. The ${ }^{1} \mathrm{H}$ NMR for compound 2 is not available.<smiles>CC(=O)C=O</smiles>

Ligand (L)<smiles>[R]OC(=O)C(=O)O[Sn](CCCC)(CCCC)OC(=O)C([O])=O</smiles>

Compound (1)

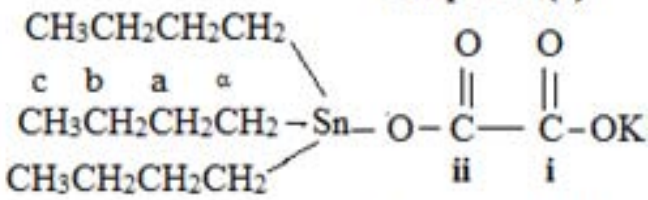

Compound (2)<smiles>CC(C)(C)OC(=O)C(=O)O[Sn](OC(=O)C(C)(C)C)(c1ccccc1)c1ccccc1</smiles>

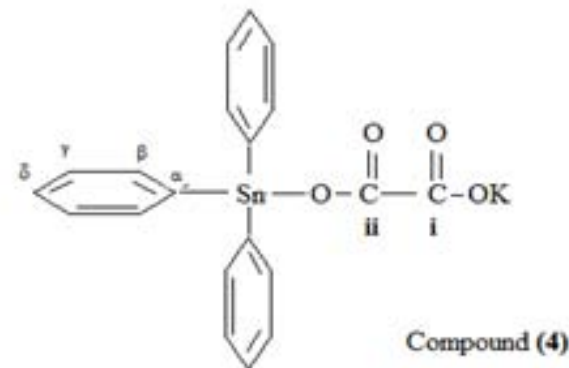

Figure 1: Numbering of protons and carbons in the Structure of synthesized compounds (1-4)

${ }^{13} \mathrm{C}$ NMR spectral data of compounds $\mathbf{1 - 4}$ are given in Table 4. The carboxyl carbons (i, ii, iii and iv) of all compounds were assigned signals in the range $162.64-175.74 \mathrm{ppm}$ which are in agreement with literature [18]. The $\mathrm{C}=\mathrm{O}$ resonance group of the complexes at $\delta 162.64-175.74 \mathrm{ppm}$ were shifted down from the position in the free ligand, which appeared at $\delta 188.17 \mathrm{ppm}$. The shift could be due to a decrease in electron density at the carbon atoms when oxygen bonded to metal ion [15], [29]. This observation indicates that, complexation in the compounds occurred through the oxygen atoms of the carboxylate group [18], [28].

Table 4: ${ }^{13} \mathrm{C}$ NMR data of synthesized compounds and ligand (ppm)

\begin{tabular}{|llllll|}
\hline Compound no. & $\mathbf{l}$ & $\mathbf{2}$ & $\mathbf{3}$ & $\mathbf{4}$ & L \\
\hline i,iv & 162.64 & 167.58 & 172.01 & 175.74 & 188.17 \\
ii,iii & 162.64 & 167.58 & 172.01 & 175.74 & 188.17 \\
a & 39.75 & 37.34 & - & - & - \\
b & 29.78 & 26.69 & - & - & - \\
G. & 28.87 & 28.28 & - & - & - \\
$\alpha$ & 26.49 & 25.98 & 144.54 & 137.36 & - \\
$\beta$ & - & - & 136.83 & 128.08 & - \\
$\gamma$ & - & - & 129.04 & 127.93 & - \\
$\delta$ & - & - & 137.05 & 135.82 & - \\
\hline
\end{tabular}

Signals for butyl carbons (a and b) appeared at 26.69 - 39.75 ppm while $-\mathrm{CH}_{3}$ designated $\alpha$, appeared at $26.49 \mathrm{ppm}$ and 25.98 ppm, respectively for compounds 1 and 2 . Phenyl carbons were assigned signals in the range $128.03-144.54$ ppm with $\alpha(\mathrm{Sn}-\mathrm{C})$ at $144.54 \mathrm{ppm}$ and $137.36 \mathrm{ppm}$ for compounds $\mathbf{3}$ and $\mathbf{4}$, respectively. These signals are in agreement with our earlier report [13], [14].

\subsection{Biological Activity}

\subsubsection{Antibacterial Activity}

Antibacterial activity tests of the ligand $(\mathbf{L})$ and its organo-tin (IV) compounds (1-4) were carried out against eight bacterial 


\section{International Journal of Science and Research (IJSR) \\ ISSN (Online): 2319-7064 \\ Index Copernicus Value (2013): 6.14 | Impact Factor (2015): 6.391}

strains; four Gram-Positive (Staphylococcus aureus, streptococcus pyogenes, Bacillus cereus and corynebacterium ulcerans) and four Gram-negative bacteria (Escherichia coli, Klebsiella pneumoniae, Proteus mirabilis and Pseudomonas aeruginosa). The results are shown in fig. 2 and 3, respectively. Erythromycin was used as standard drug in this assay. Reports have shown that criteria for activity is based on zone of inhibition ( $\mathrm{mm}$ ); inhibition zone more than $20 \mathrm{~mm}$ shows significant activity, for $18-20 \mathrm{~mm}$ inhibition activity is good, $15-17 \mathrm{~mm}$ is low, and below 11$14 \mathrm{~mm}$ is non-significant [23],[24],[27]. The results revealed that all the synthesized compounds showed significant activity against all tested bacterial strains with zones of inhibition ranging from 21-32 mm. However, there were few cases where the compounds, ligand and standard drug did not show activity against some strains. Generally, compounds 14 were more active against gram-positive bacteria than the gram-negative ones. Even though, erythromycin showed higher activity ranging from 28-34 mm, it showed no activity against Bacillus cereus, Proteus mirabilis and Pseudomonas aeruginosa.

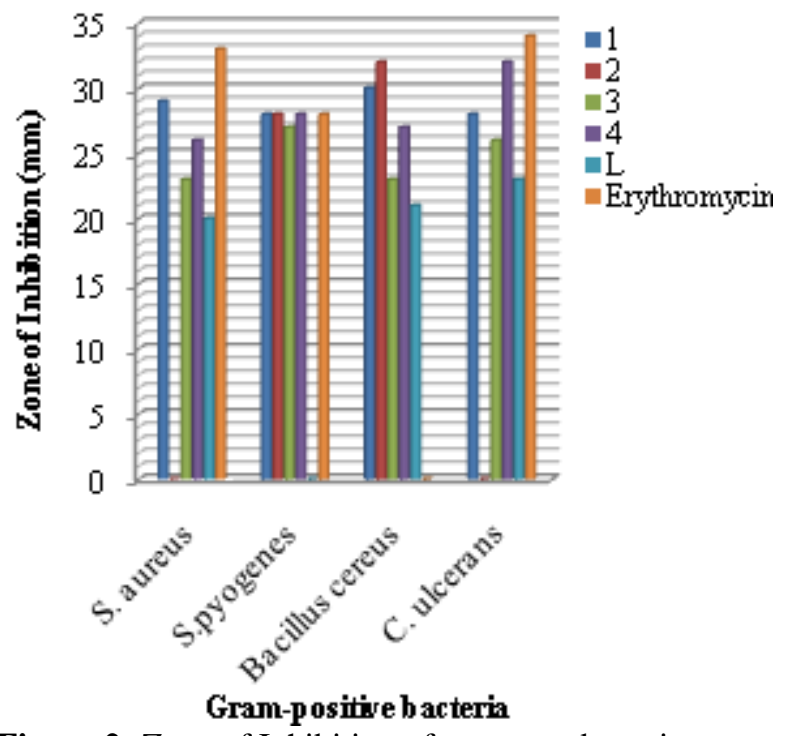

Figure 2: Zone of Inhibition of compounds against gram positive bacteria

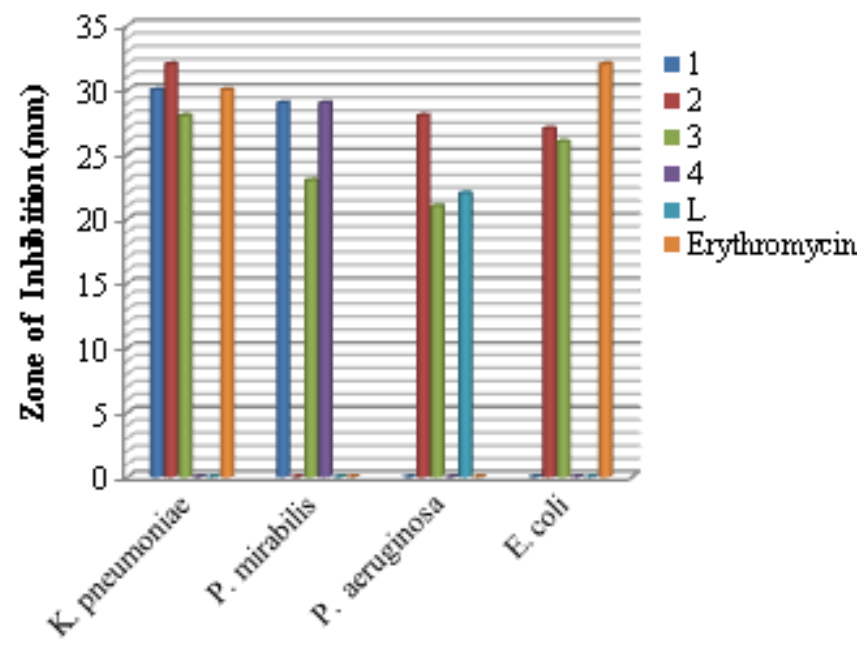

Gram-negative bacteria

Figure 3: Zone of Inhibition of compounds, drug and ligand against gram positive bacteria
It was noted that compounds $\mathbf{1}, \mathbf{3}$ and $\mathbf{4}$ exhibited significant activity against Staphylococcus aureus (29, 28 and $26 \mathrm{~mm})$, streptococcus pyogenes $(28,27 \& 28 \mathrm{~mm})$, Bacillus cereus (30, 23 \& $27 \mathrm{~mm}$ ) and corynebacterium ulcerans (28, 26 \& $32 \mathrm{~mm}$ ) with compound 4 exhibiting the highest activity against corynebacterium ulcerans $(32 \mathrm{~mm})$ very close to the activity of erythromycin. The ligand $\mathbf{L}$, showed no activity against streptococcus pyogenes but exhibited lowest activity for the other gram-positive bacterial strains. Despite the significant activity of the standard drug used, it did not show any activity against Bacillus cereus but compounds 1-4 did. Compounds 1, 2and $\mathbf{3}$ exhibited the same activity with erythromycin $(28 \mathrm{~mm})$ against streptococcus pyogenes (fig. 2). For the gram-negative bacteria, Fig. 3 demonstrates that compounds $\mathbf{1}$ and $\mathbf{2}$ showed significant activity against Klebsiella pneumoniae and also greater than the reference drug while compound $\mathbf{3}$ exhibited significant activity (28 $\mathrm{mm}$ ) very close to the standard drug. On the other hand, compound $\mathbf{4}$ and $\mathbf{L}$ exhibited no activity against the said bacteria. Compound $\mathbf{4}$ and $\mathbf{L}$ only exhibited activity against Proteus mirabilis $(20 \mathrm{~mm})$ and Pseudomonas aeruginosa (28 $\mathrm{mm}$ ) respectively. The antibacterial study also demonstrates that compound $\mathbf{3}$ exhibited significant activity against all the gram-negative bacteria (Escherichia coli, Klebsiella pneumoniae, Proteus mirabilis and Pseudomonas aeruginosa). In general, compounds 2 and 4, the triorganotin (IV) compounds showed greater antibacterial activity than compounds 1 and 3, the diorganotin (IV) counter parts. This is consistent with literature and may be due to greater lipophilicity and permeability through the cell membrane [23], [24], [27]. MIC of the compounds was obtained at the concentrations of $15 \mu \mathrm{g} / \mathrm{mL}$ while their MFC revealed that all the bacteria were not just inhibited but were completely killed at the same concentration.

\subsubsection{Antifungal Activity}

The ligand $\mathbf{L}$ and its organotin (IV) compounds (1-4) werescreened for antifungal activity against four fungal strains (Microsporum audounii, Microsporum distortum, Microsporum gallinae and Microsporum gypseum) by using agar tube dilution method [21] - [23]. From the result shown in fig. 4, it was observed that all the compounds exhibited significant activity against test fungi with compounds $\mathbf{2}$ and $\mathbf{4}$ (trioganotin (IV) compounds) exhibiting the highest activity against Microsporum audounii \& Microsporum gallinae (29 $\mathrm{mm}$ ) and Microsporum distortum (28 mm), respectively. These activities were close to those exhibited by the standard drugs fulcin and fluconazole $(30-34 \mathrm{~mm})$. Despite the significant activity exhibited by both standard drugs, they did not exhibit activity against Microsporum distortum but compounds 1-4 showed significant activity with zones of inhibition ranging from $24-28 \mathrm{~mm}$. Fulcin, only exhibited activity against Microsporum gallinae $(30 \mathrm{~mm})$. Of all the compounds synthesized, only compound 2 exhibited activity against all the test fungi with zones of inhibition ranging from 26 - $29 \mathrm{~mm}$. Compound 4 showed activity only against Microsporium distortum at the concentrations used. Overall, compounds $\mathbf{1}-\mathbf{4}$ showed good antifungal activity at the concentration used. MIC of the compounds was obtained at the concentrations of $25 \mu \mathrm{g} / \mathrm{mL}$ while their MFC revealed that all the fungi were not just inhibited but were completely killed at the same concentration. 


\section{International Journal of Science and Research (IJSR) \\ ISSN (Online): 2319-7064 \\ Index Copernicus Value (2013): 6.14 | Impact Factor (2015): 6.391}

The increased antibacterial and antifungal activities observed in compounds 1- 4 than their ligand could be due to the presence of metal ions introduced into their structures when the ethanedioc acid $(\mathrm{HOOCCOOH})$ was coordinated with $\mathrm{K}^{+}$ and $\mathrm{Sn}^{4+}$. This agrees with the known fact that many biologically active compounds become more active upon complexation than in their uncomplexed forms [18]. Findings have shown that organotin (IV) carboxylates are more active than their ligand which is in agreement with literature [15, 18].

The biological activity of organotin compounds especially diorganotin (IV) compounds have been reported

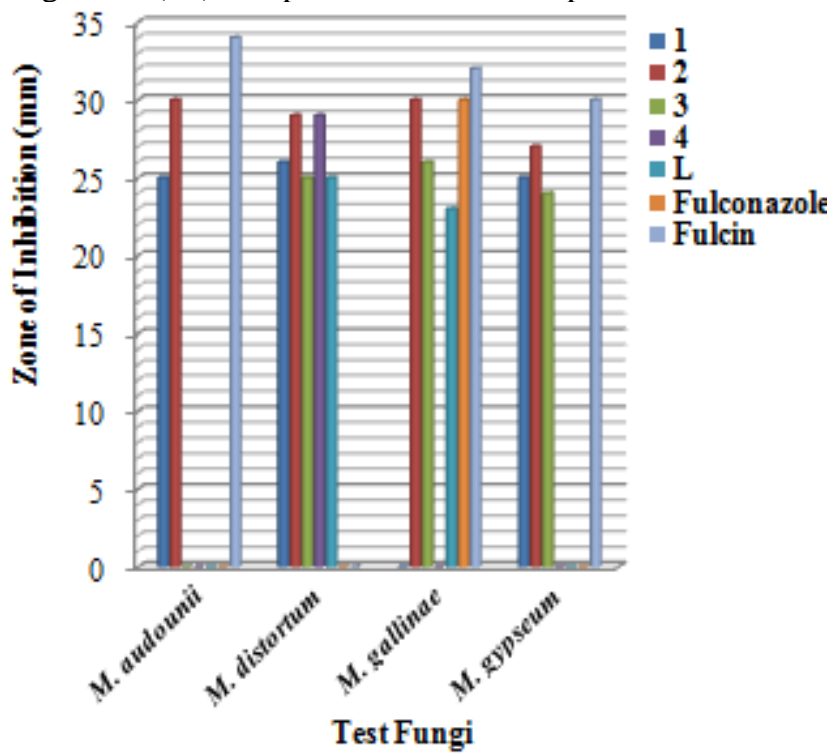

Figure 4: Zone of Inhibition of compounds, drug and ligand against test fungi

to depend solely on the organotin moiety; $\mathrm{R}_{2} \mathrm{Sn}^{2+}$ and $\mathrm{R}_{3} \mathrm{Sn}^{+}[5]$. Carboxylate groups are known to influence the delivery of organotin (IV) moiety to the point of action. Therefore, the activities of compounds $\mathbf{1 - 4}$ appeared to be a combined effect of the metal ions and carboxylate groups. Since diorganotin (IV) compounds (1 and 3) are not known for their high biological activities, their activity in this study could propably be due to the presence of potassium and Sn ions in their structures [29].

\section{Conclusion}

A series of four organotin (IV) carboxylate compounds of potassium hydrogen ethanedioate synthesized and characterized by FT-IR, ${ }^{1} \mathrm{H}$ NMR and ${ }^{13} \mathrm{C}$ NMR, FTIR spectra revealed that the modes of coordination in compounds (1) and (2) are bidentate and in compounds (3) and (4) are monodentate while NMR confirmed the formation of compounds. Generally, all the compounds exhibited significant antimicrobial activity comparable to standard drugs used. Compound (4), $\mathrm{Ph}_{3} \mathrm{SnL}$ exhibited antibacterial activity more than its diphenyl counterpart, compound (3): $\mathrm{Ph}_{2} \mathrm{SnL}_{2}$ while compound (1), $\mathrm{Bu}_{2} \mathrm{SnL}_{2}$ exhibited higher activity than compound (2), $\mathrm{Bu}_{3} \mathrm{SnL}$ against gram-positive bacteria. The observation that the triorganotin (IV) compounds :(4) is more active agrees with the notion that the number of carbon atoms in an organotin moiety affects biological activity [29] of the compound. For gram- negative bacteria, compound (2), $\mathrm{Bu}_{3} \mathrm{SnL}$ exhibited more activity than compound (1), $\mathrm{Bu}_{2} \mathrm{SnL}_{2}$ while compound (3) $\mathrm{Ph}_{2} \mathrm{SnL}_{2}$ exhibited more activity than compound (4), $\mathrm{Ph}_{3} \mathrm{SnL}$. Antifungal activity revealed that $\mathrm{Bu}_{3} \mathrm{SnL}$ exhibited activity more than its $\mathrm{Bu}_{2} \mathrm{SnL}_{2}$ counterpart while $\mathrm{Ph}_{3} \mathrm{SnL}$ was more active than $\mathrm{Ph}_{2} \mathrm{SnL}_{2}$ its counterpart. The order for the antifungal activity in this study was $\mathrm{Bu}_{3} \mathrm{SnL}>\mathrm{Ph}_{3} \mathrm{SnL}>$ $\mathrm{Ph}_{2} \mathrm{SnL}_{2}>\mathrm{Bu}_{2} \mathrm{SnL}_{2}$. The order of activity against grampositive bacteria was $\mathrm{Ph}_{3} \mathrm{SnL}>\mathrm{Bu}_{2} \mathrm{SnL}_{2}>\mathrm{Ph}_{2} \mathrm{SnL}_{2}>$ $\mathrm{Bu}_{3} \mathrm{SnL}$. The order of activity against gram-negative bacteria was $\mathrm{Bu}_{3} \mathrm{SnL}>\mathrm{Bu}_{2} \mathrm{SnL}_{2}>\mathrm{Ph}_{2} \mathrm{SnL}_{2}>\mathrm{Ph}_{3} \mathrm{SnL}$.

\section{Acknowledgement}

The authors would want to appreciate the Almighty God for grace to embark on this research. Our thanks goes to University of Agriculture Makurdi-Nigeria, Benue State University Makurdi-Nigeria, National Research Institute for Chemical Technology (NARICT) and Dr J. Igoli of the Institute of Pharmaceutical Chemistry, University of Strahtclyde, Glasglow, United Kingdom and University of Agriculture, Makurdi-Nigeria. Special thanks also go to Prof. R. Sha'Ato and Dr A Mikailu of University of Agriculture, Makurdi-Nigeria and Medicinal Microbiological Department, Ahmadu Bello University Teaching Hospital, Zaria- Kaduna respectively.

\section{References}

[1] M. Gielen, M. Biesemans, R. Willem, Organotin compounds: from kinetics to stereochemistry and antitumour activities, Applied Organometallic Chemistry, 19: 440-450, 2005.

[2] N. Awang, J. Baba, N. S. A. Mohdyusuf, N. F.Kamalodin, "Synthesis and Characterisation of Organotin(IV) N-benzyl-N-isopropyldithiocarbamate Compounds: Cytotoxic Assay on Human Hepatocarcinoma cells (HepG2)", American Journal of Applied Sciences. 7(8), pp. 1047-1052, 2010.

[3] L. Angiolini, D. Caretti, L. Mazzocchetti, E. Salatelli, R. Willem, M. Biesemans, Triorganotin-4vinylbenzoates: assessment of their catalytic activity in transesterification reactions, Journal ofOrganometallic Chemistry, 691, 3043-3052, 2006.

[4] E. Yousif, B. I. Mehdia, R. Yusop, J. Salimon, N.Salih and B. M. Abdullah. Synthesis, structure and antibacterial activity of some triorganotin(IV) complexes with a benzamidoalanine ligand, Journal of Taibah University for Science 8: 276-281, 2014.

[5] B.Traore, L. Diop, M. Sidibe,"New Halo- and Organotin (IV) Phenyl arseniato Adducts and Derivatives", Scientific Study and Research. 13 (4), pp.387-391, 2012.

[6] M.Gielen, An Overview of Forty Years Organotin Chemistry Developed at the Free Universities of Brussels ULB and VUB, Journal of the Brazilian Chemical Society, 14 (6), 870-877, 2003.

[7] C.Ma, B. Zhang, S. Zhang, R. Zhang, "Chiral organotin (IV) carboxylates complexes: Syntheses, characterization, and crystal structures with chiral (S) (+)-6-methoxy- $\alpha$ methyl-2-naphthaleneaceto acid 


\section{International Journal of Science and Research (IJSR) \\ ISSN (Online): 2319-7064}

Index Copernicus Value (2013): 6.14 | Impact Factor (2015): 6.391

ligand", Journal of Organometallic Chemistry, (696),pp 2165-2171, 2011.

[8] M. Hussain, M.Zaman, M.Hanif, S. Ali and M. Danish.Synthesis and structural characterization of organotin (IV) complexes formed with $[\mathrm{O}, \mathrm{O}]$ donor atoms of carboxylic acidsJournal Serbian Chemical Society, 73 (2) 179-187, 2008.

[9] H. Pruchnik, F. P. Pruchnik, "Butyltin (IV) Citrates and Tartrates: Structural Characterization and their Interaction with Nucleotides", Journal of Organometallic Chemistry, 729, pp. 60-67, 2013.

[10] C.Ma, B. Zhang, S. Zhang and R. Zhang .Chiral organotin (IV) carboxylates complexes: Syntheses, characterization, and crystal structures with chiral (S) (+)-6-methoxy- $\alpha$ methyl-2-naphthaleneaceto acid ligand. Journal of Organometallic Chemistry, 696: 2165-2171, 2011.

[11] M. M.Amini, A. Amirreza, A.Vajiheh, R, K. Hamid, H, Taraneh, N. K. Ali, "Di and triorganotin (IV) Carboxylates derived from triorganotin (IV) iodide with mixed organic groups on tin: Cyclic, hexameric triorganotin (IV) carboxylates", Inorganica Chimica Acta, 362, pp. 355 - 360, 2009.

[12] S. Shahzadi, K. Shahid, S. Ali, Z. Akhtar,Organotin (IV) Complexes on Aniline Derivaties Part-II-Synthesis and Spectroscopic Characterization of Organotin (IV) Derivatives of 2-[4-Bromoanailine) carboxyl] benzoic Acid, Turkish Journal of Chemistry, (27) 209 - 215, 2003.

[13] E. N Iornumbe, Synthesis, Aqueous Solubility and Antifungal Studies of Some Organotin (IV) Dicarboxylates, Ph.D Thesis, Univeristy of Agriculture Makurdi-Nigeria, 2015.

[14] E. N. Iornumbe, S. G .Yiase, R. Sha'Ato, T. A. TorAnyiin, Synthesis, Characterization and Antifungal Activity of Some Organotin (IV) Derivatives of Octanedioic Acid, International Journal of Science and Research, 4(5), 2095-2101, 2015.

[15] E. N. Iornumbe, S. G .Yiase, R. Sha'Ato, T. A. TorAnyiin, Synthesis, Characterization and Antifungal Activity of Some Organotin (IV) Derivatives of Hexanedioic Acid, IOSR Journal of Applied Chemistry, 8(6), 07-15, 2015

[16] S. G. Yiase, "Synthetic, Spectroscopic, Formulation and Anti-Mycotic Studies of some Organotin and Organosilicon Compounds" Ph.D Thesis, Department of Chemistry. Ahmadu Bello University, Zaria, Nigeria, 211p, 2002.

[17] J.Szorcsik, A. Nagy, L. Pellerito, T. Yamaguchi, K. Yoshida, "Preparation and Structural Studies on Organotin (IV) Complexes formed with Organic Carboxylic Acids", Journal of Radioanalytical Chemistry, 256 (1),pp 3-10, 2003.

[18] Q. M. Amua, "Synthesis, Characterization and Aqueous solubility studies of some Organotin (IV) Carboxylates", M.Sc Thesis. Benue State University, Makurdi-Nigeria, 62p, 2006.

[19] S.Hadi, R. Mita, Nurhasanah, "Comparative Study on the Antifungal Activity of some Di- and Tributyltin (IV) Carboxylate Compounds. Modern Applied Science Journal, 3(1), pp. 12-17, 2009.
[20] S.Hadi, B. Irawan, Efri, "Antifunal Activity Test of some Organotin (IV) Carboxylates", Journal of Applied Science Research, 4(11), pp 1521-1525, 2008.

[21] M.Farnsworth, J. Pekola, "Determination of Tin in Inorganic and Organic Compounds and Mixtures", Journal of Analytical Chemistry, (31), pp.410 413,1959.

[22] M. Cheesbrugh, District Laboratory Practices in Tropical Countries Part 1. Cambridge University Press, Cambridge, 2000.

[23] S. Hadi, B. Irawan, Efri, Antifunal Activity Test of some Organotin (IV) Carboxylates, Journal of Applied Science Research, 4(11), 1521-1525, 2008.

[24] S.Ahmed, M. H. Bhatti, S. Ali, F. Ahmed, "Organotin (IV) Derivatives of 1-Ethyl 1,4-Dihydro-7-Methyl-4Oxo-1,8-Naphthyridine-3-Carboxylic Acid (Nalidixic Acid): Synthesis, Structural Elucidation and Biological Activities. Turkish Journal of Chemistry, (30), pp. 193 - 202, 2006.

[25] M. Tariq, S. Ali, A. N. Shah, N. Muhammad, N. M. Tahir, N. Khalid, R. M. Khan, "Catalytic, Biological and DNA Binding Studies of Organotin (IV) Carboxylates of 3-(2-fluorophenyl)-2-methylacrylic acid: Synthesis, spectroscopic characterization and Xray structure analysis", Polyhedron, (57) 127-137, 2013.

[26] X. Xiao, D. Dafeng, H. Xiao, L. Jingwen, T. Min, Z. Dongsheng, X. Lin,“ Self-assembly of triorganotin (IV) moieties with 1,2,4,5-benzene tetracarboxylic acid: Synthesis, characterizations and influence of solvent on the molecular structure". Journal of Organometallic Chemistry, 713, pp. 143-150, 2012.

[27] M. A. Choudhary, M. Mazhar, U. Salma, S. Ali, X. Q. Lan, K. C. Molloy, "Synthesis and Characterization of Organotin Compounds containing Silicon and Germanium and Crystal structure of Precursor Carboxyl-ethyltrichlorogermanium "Synthetic Reactions of Inorganic Metal- organonotin Chemistry,(31) 277-295, 2001.

[28] T.Muhammad, A. Saqib, A. S. Naseer, M. Niaz, N. T. Muhammad, K. Nasir, R. K. Muhammad,"Catalytic, biological and DNA binding studies of Organotin (IV) carboxylates of 3-(2-fluorophenyl)-2-methylacrylic acid: Synthesis, spectroscopic characterization and Xray structure analysis "Polyhedron,(57), pp 127-137, 2013.

[29] A. S.Farooq, S. Muhammad, A. Saqib, M. A. Syed, N. T. Muhammad, R.Corrado,"Synthesis, spectroscopic characterization, X-ray structure and biological screenings of organotin (IV) 3-[(3,5dichlorophenylamido)] propanoates", Inorganica Chimica Acta, 400, 159 - 168, 2013.

[30] A.Szorcsik, L. Nagy, K. Gadja-Schrantz, L. Pellerito, E, Nagy, E. T. Edelmann, "Structural studies on Organotin(IV) complexes formed with ligands containing $\{\mathrm{S}, \mathrm{N}, \mathrm{O}\}$ donor atoms", Journal of Radioanalytical Nuclear Chemistry, 252 (3), pp. 523 530, 2002. 


\section{International Journal of Science and Research (IJSR) \\ ISSN (Online): 2319-7064 \\ Index Copernicus Value (2013): 6.14 | Impact Factor (2015): 6.391}

\section{Author Profile}

Dr. Esther Nguumbur Iornumbe holds a B.Sc (Hons) Chemistry and M.Sc. Analytical Chemistry from the Benue State University, Makurdi in 2000 and 2008 respectively. She bagged a Ph.D in Inorganic Chemistry at the Federal University of Agriculture, Makurdi. She is currently a Lecturer in the Department of Chemistry, Federal University of Agriculture, Makurdi.

Dr. Stephen GbaoronYiasereceived B.Sc (Hons) in Chemistry from Ahmadu Bello University Zaria Nigeria, He later proceeded to the University of Sheffield, United Kingdom where he obtained a Diploma and Master of metallurgy, He returned to Ahmadu Bello University Zaria and obtained a Ph.D in Chemistry. He is currently a Senior Lecturer in the Department of Chemistry, Benue State University, Makurdi.

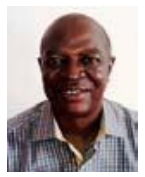

Dr. TerrumunAmom Tor - Anyiin holds B.Sc (Hons) Chemistry from the Bayero University Kano, M.Sc (Pharmaceutical Chemistry) at the Ahmadu Bello University Zaria and Ph.D in Organic Chemistry from the Nnamdi Azikiwe University, Awka. He is currently an Associate Professor in the Department of Chemistry and the Deputy Dean of Post graduate School, Federal University of Agriculture, Makurdi. 